istry - keen to find an acceptable and costeffective alternative to vasectomy (it is estimated that a single injection would cost less than US\$0.30) - Guha is pushing ahead with a clinical trial to test the efficacy of the technique in humans. The trial began in January, and surgeons at the Lok Nayak Jaya Prakash Hospital have already injected 30 young, married male volunteers (all with children) with the polymer. A total of 120 men will eventually be recruited as part of a multicentre study to test both efficacy and reversibility.

Badri Saksena, deputy chief of the Indian Council of Medical Research, one of four institutions taking part in the study, and head of the council's reproductive research programme, expects that it will take two years to determine the polymer's efficacy, and another year to find out if its effect is reversible.

The council funded all of Guha's earlier work but was not willing to support for the latest trial (so the health ministry stepped in as sponsor) until his team had demonstrated that the procedure could be reversed.

"The fact that it was reversed in animals does not mean it would work in humans," says Saksena. The council also insisted that Guha show that the polymer is not toxic in non-target organs (the vas deferens is about $0.6 \mathrm{~mm}$ in diameter and so may be difficult for inexperienced technicians to locate).

Guha says that the question of toxicity in non-target tissues was answered in the earlier safety trial: none of the 46 male volunteers experienced any adverse reaction in the three years of follow-up. Moreover, Guha claims that in a few cases he has shown that the technique can be reversed, although the data are not published.

How the polymer works as a contraceptive is not clear. Scanning electron microscope studies and enzyme assays have, however, given Guha's team clues. From these studies it appears that membranes covering the head of sperm fracture on contract with the polymer, resulting in leakage of enzymes that are essential if penetration of the egg is to be successful.

Apart from obtaining a better understanding of the mechanisms involved, Guha's team also hopes to improve the technology for polymer delivery. Now, surgeons must make an incision to expose the vas so that the needle can be inserted. Guha hopes in future to be able to avoid this minor surgery, so that the procedure is as simple as a subcutaneous injection.

K. S. JAYARAMAN New Delhi

\title{
French review research strategy
}

The French government has promised FF257 million (US\$51 million) more than two years to support a new national strategy for research in the life sciences in a move that it claims demonstrates its 'commitment' in this area. Many researchers are concerned, however, that the new strategy will represent more centralized control over research spending and the creation of a 'super' research council within the ministry of higher education and research. Moreover, many have yet to be convinced that much new money will be forthcoming.

Under the new plans, seven research areas have been singled out as priority areas, within which there will be 14 programmes or themes (see box). Each programme will be administered directly by a scientific committee created within the ministry, such that the ministry itself will make calls for research proposals and will make decisions on who gets funded.

Members of the committee will be appointed by the ministry from lists proposed by the main research agencies, the Centre National de la Recherche Scientifique (CNRS), the biomedical research agency, the Institut Nationale pour la Santé et Recherche Medicale (INSERM), and other research organizations.

Reaction to the proposals among researchers has been mixed. Some observers welcome the ministry's decision to focus funding for the life sciences, which they claim has become too fragmented. But Pierre Chambon, director of the Institute of Genetics and Molecular and Cell Biology in Strasbourg, also warns that the move could mean that basic research may be sacrificed in favour of research funded on a shortterm basis.

Scepticism has been heightened because overall state funding of research, including the life sciences, is being cut back. "At the same time as our budgets are being lowered, we are now being told of new measures which won't produce any new funds until the autumn," says Chambon.

Another concern is that only FF153 million (US\$30 million) of the proposed FF 257 million will be made available for the new programme this year; the remainder will still be subject to approval by parliament this autumn. Adding to the uncertainty is the prospect that François Fillon, science minister and the main architect of the new strategy, is likely to be replaced following the presidential elections in May.

\begin{tabular}{|c|c|}
\hline \multicolumn{2}{|c|}{ Priority programmes } \\
\hline Genetics & $\begin{array}{l}\text { - Genome structural and } \\
\text { functional analysis } \\
\text { - Human genetics } \\
\text { - Genetics and the } \\
\text { environment }\end{array}$ \\
\hline \multicolumn{2}{|c|}{$\begin{array}{l}\text { Developmental biology, } \\
\text { reproduction and ageing }\end{array}$} \\
\hline \multicolumn{2}{|c|}{$\begin{array}{l}\text { Structural biology and } \\
\text { pharmacochemistry }\end{array}$} \\
\hline $\begin{array}{l}\text { Environmental } \\
\text { sciences }\end{array}$ & $\begin{array}{l}\text { - Microbiological } \\
\text { ecosystems } \\
\text { - Systematics and } \\
\text { biodiversity } \\
\text { - Biological effects of } \\
\text { ionizing radiation }\end{array}$ \\
\hline $\begin{array}{l}\text { Physiopathological } \\
\text { mechanisms }\end{array}$ & $\begin{array}{l}\text { - Cardiovascular } \\
\text { physiopathology and } \\
\text { pharmacology } \\
\text { - Prion biopathology } \\
\text { - Cell imaging and } \\
\text { mechanics in neuro- } \\
\text { biopathology } \\
\text { - Multidisciplinary } \\
\text { development of } \\
\text { functional imaging }\end{array}$ \\
\hline \multicolumn{2}{|l|}{ Bioinformatics } \\
\hline Biotechnology & \\
\hline
\end{tabular}

Another concern is that these funds may not represent new money. "Are we talking about extra money or simply a transfer of money [to the ministry] which would usually be given to the research organizations?" asks Axel Kahn, head of the Institute of Genetics and Molecular Biology in Paris. "We will see if this has any effect in the budget of organizations in 1996."

Pierre Tambourin, director of life sciences at CNRS - which has had its general budget cut 13 per cent during the past two years - claims, for example, that some of the areas he had given priority to within his institute, such as the biology of ageing and structural biology, have almost come to a standstill as a result.

As part of the effort to develop a national strategy for the life sciences, the ministry in late February announced its plans to take control of three-quarters of the FF80 million (US\$16 million) budget previously allocated this year to the national genome agency GREG (Groupement de Recherches et d'Etudes sur les Génomes. "If the ministry doesn't trust the research organizations, then why not simply say so and appoint new directors," says one CNRS official.

Fillon refutes such claims, and says that the new framework is simply more "flexible and efficient."

Catherine TASTEMAIN Paris 